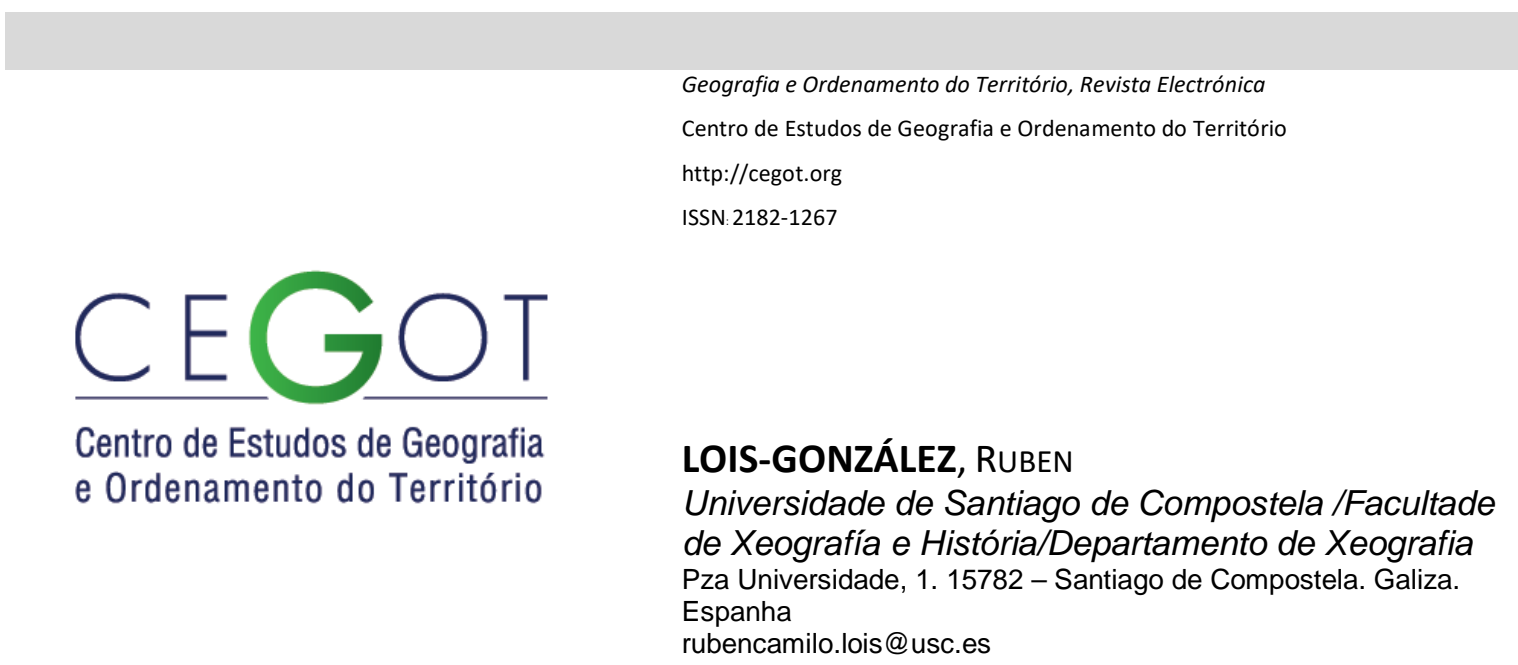

\title{
Galiza no espaço lusófono. Uma aproximação a partir da Geografia
}

\author{
Galicia in the Lusophone space. An approach from the Geography
}

Referência: Lois-González, Rubén (2016). Galiza no espaço lusófono. Uma aproximação a partir da Geografia. Revista de Geografia e Ordenamento do Território (GOT), n. 10 (dezembro). Centro de Estudos de Geografia e Ordenamento do Território, p. 9-33, dx.doi.org/10.17127/got/2016.10.001

\section{RESUMO}

No presente trabalho aponta-se como a semelhança cultural e linguística entre o galego e o português, assim como a proximidade que outorga a raia do Minho, permite reinterpretar a geopolítica da Galiza, Portugal e a lusofonia, a prol de um maior achegamento e integraçâo. De fato, a Galiza é o território espanhol mais próximo a Portugal em muitos sentidos. Também constitue uma continuidade do eixo urbano atlântico que, desde Setúbal até $A$ Corunha-Ferrol define o corredor de maior concentraçâo urbana e econômica da Península Ibérica. A Galiza e o Portugal formaram um reino e uma língua comum nos inícios da Idade Média. Na atualidade as suas relaçôes econômicas, medidas em Investimentos Exteriores Diretos e comércio exterior, multiplicaram-se desde a integraçâo nas Comunidades Europeias. O nascimento e consolidaçâo duma Eurtorregiâo entre a Comunidade Autônoma de Galiza e a Regiâo Norte de Portugal ele faz, mas afirmar, o interesse duma cooperaçâo interterritorial acrescentada. A Geografia deve compreender e explicar este importante processo recente que introduz uma realidade a diferentes escalas no mundo globalizada dos começos do século XXI.

Palavras-chave: Lusofonia, integraçâo territorial, geopolítica, afinidade linguística, Galiza, Portugal

\section{ABSTRACT}


In this work points the cultural and linguistic similarity between Galician and Portuguese, as well as the proximity to which gives the streak of Minho, lets reinterpret close the geopolitics of Galicia, Portugal and lusophony. Galicia is Spain closer to Portugal in many senses. It constitutes also a continuity of urban Atlantic axis that since Setubal until A Coruña-Ferrol defines the largest urban and economic concentration of the Iberian Peninsula. Galicia and Portugal formed a Kingdom and a common language at the beginning of the middle age. Today their economic affairs, Foreign Direct Investments and measures in foreign trade, have multiplied since the soul integration in the European Community. The birth and consolidation of a Euroregion between the Autonomous Community of Galicia and the Northern Region of Portugal, but say the interest an inter-territorial cooperation added. Geography should understand and explain this important process that introduces a reality the different scales in the globalized world of the 21ST century starts.

Keywords: Lusophony, territorial integration, geopolitics, linguistic affinity, Galicia, Portugal

A análise histórica das últimas décadas ${ }^{1}$ mudou profundamente a partir dos trabalhos de vários autores anglo-saxónicos, que conseguiram recuperar o protagonismo esquecido da história política a partir dos conceitos "invenção da tradição" e "comunidade imaginada" (Anderson, 1983; Howsbann, 1983). Em função dos mesmos, o passado dos territórios e a constituição dos Estados-nação, já não responde a uma acumulação de evidências seculares sobre a integração de pequenos lugares e regiões até acabar na dimensão de um país completo. As nações e o nacionalismo surgem antes como ideias contemporâneas (popularizadas desde França e da Revolução Francesa), e essa vontade iniciada no século XIX de justificar a existência imemorial de um Estado, conduziu à criação de identidades nacionais inventadas nos distintos países e territórios nacionais, que não possuíam nesse momento aparato estatal próprio, no sentido contemporâneo do termo. A construção da história nacional foi um modelo em França, Alemanha, Itália e Portugal, por distintas razões. A Espanha, ou o Estado Espanhol, seguiu um processo mais turbulento como têm analisado de forma autorizada diversos historiadores (Álvarez Junco, 2001; Moreno y Núñez Seixas, 2013). Na realidade, a definição da essência de Espanha, no seu longo caminho em direção à unidade nacional, coincidiu no tempo com a afirmação literária e histórica de outros

\footnotetext{
${ }^{1}$ Este trabalho surge de uma dívida académica contraída com os meus amigos Elías Torres Feijó e Jose A. Rio Fernandes. Para escrevê-lo tomei a decisão de rever durante muito tempo todos os conteúdos da revista Veredas e da Algália, editada pela Asociaçom Galega da Língua. Com este trabalho pude verificar uma marcada hegemonia do discurso linguístico, de crítica literária e, em menor medida, dos estudos culturais, e de uma quase ausência da análise geográfica e/ou cartográfica nestes dois meios tão influentes no mundo lusófono, em geral, e entre os partidários da reintegração linguística do galego com o português em particular. Há notáveis exceções a esta regra como as aportações de Camilo Nogueira e Joam Bernardes Vilar em Algália, mas considero que a análise espacial e territorial é deficitária. Por isso, trato de elaborar um discurso da Galiza na lusofonia partindo de um raciocínio geográfico.
} 
territórios incluídos nela, tais como a Catalunha, o País Basco ou Galiza. Nesta última, junto ao papel dos autores do rexurdimento como R. Castro, E. Pondal ou Curros Enríquez, os tratadistas M.Murguia e B. Vicetto construíram o passado do país a partir das suas raízes célticas por oposição aos iberos de Espanhã (Beramendi, 2008). Nestes momentos precoces da segunda metade do século XIX já se produziu a justaposição de dois processos de construção identitária nacional, o espanhol e o galego, remarcando os aspetos antagónicos relativos ao território que definia o Estado-nação de pertença.

Se esta primeira etapa de construção discursiva da nações foi muito importante, os decénios dos anos 1920 e 1930 não o serão menos. Nesta época, uma nova declaração do pensamento galeguista/nacionalista articula-se a partir do Seminário de Estudos Galegos e da revista Nós, onde se elaborará uma autêntico discurso académico sobre a Galiza, com referência à história, à etnografia, à arqueologia, à geografia, e evidentemente à língua, assim como ao direito próprio, entre outras. A Xeración Nós, com líderes políticos de tanta relevância como A.R. Castelao ou teóricos como V. Risco e R. Otero Pedrayo, ainda que não o afirmasem explicitamente, abrem uma leitura da realidade nacional da Galiza como contraposta a Castela e unida de forma natural a Portugal (Beramendi e Maiz, 1991; Beramendi, 2008). Castela é a imagem negativa, com monótonas paisagens ocres, com uma experiência traumática da emigração temporal dos galegos para a sega e com uma cidade esmagadora como Madrid. Pelo contrário, o país vizinho luso possui a mesma lógica de um velho complexo agrário como o próprio, especialmente no Norte, mostra um enorme protagonismo das freguesias ou da propriedade comum, fala uma língua próxima (particularmente as suas variantes minhotas) e coincide com a Galiza em múltiplos aspetos culturais. O progressivo descobrimento de uma tradição poética medieval conjunta será uma evidente afirmação desta vinculação sempre reivindicada.

Como tive a ocasião de assinalar há anos (Lois, 2002), os galegos foram lusistas, iberistas (no sentido de reivindicar a unidade política federal ou confederal da Península), sempre próximos do irmão do sul, procurando sublinhar as suas diferenças em relação ao resto dos espanhóis. Essas coincidências mantiveram-se com intensidade no eixo político, muito influenciado pela enorme satisfação e caráter exemplar que adquiriu a Revolução do 25 de abril entre os jovens universitários e os opositores a Franco ao longo do país. Não obstante, desde os anos 1970 toda a intensa vinculação Galiza-Portugal viu-se mediatizada pelo debate linguístico à volta da condição do galego, como língua própria, essencial para um pequeno território e isolada, ou pertencente à família lusófona. Este debate sobre normas e modelo de normalização do galego reforçou o papel dos filólogos como mediadores da interpretação da Galiza como integrada ou não nos países de língua oficial portuguesa e, em certa medida, da Galiza e do galego desde Portugal, Brasil ou Cabo Verde ( de facto, sempre 
sem a desvincular de uma espanholidade consubstancial). De forma muito esquemática poderia dizer-se que a Filologia adquiriu um papel central no discurso perante a importância da História, da Economia política e, evidentemente, da Geografia.

E, contudo, nos últimos decénios voltaram a situar a dimensâo territorial, o geográfico, como um poderoso fator explicativo da unidade, ou da convergência de interesses entre Galiza e a lusofonia. As recentes dinâmicas de integração territorial operadas na Europa e, muito especialmente, o processo de globalização, introduziram novas possibilidades de afirmação da personalidade própria da Galiza junto a Portugal e, em geral, ao mundo lusófono. Por um lado, a incorporação dos territórios ibéricos nas comunidades Europeias no ano 1986 fez desaparecer a fronteira entre Espanha e Portugal, pelo menos no que a limitações de trânsito de pessoas e de mercadorias se refere. Este facto, unido à disponibilização de consideráveis volumes de fundos europeus de cooperação transnacional (ou transfronteiriça), refletiu-se numa melhoria substancial das infraestruturas de comunicação, no surgimento de experiências conjuntas de desenvolvimento local e num melhor conhecimento dos responsáveis públicos de um e de outro lado da fronteira, entre outros efeitos (Papeles de Economía Española, 1994; Meixide e De Castro, 2001; Eixo Atlántico, 2004). No caso da Galiza e de Portugal, duas entidades nacionais vizinhas, com uma língua e cultura marcadas pelas afinidades, este novo período trouxe uma multiplicação dos contatos entre ambos territórios. As deslocações de galegos para Portugal, e de cidadãos portugueses para a Galiza, são contínuos, quantifica-se em centenas de milhares por motivos turísticos de lazer ou de compras todos os anos. Ao mesmo tempo, os intercâmbios de produtos elaborados entre os dois países são 20 ou 25 vezes maiores atualmente que nos anos 1980 (Lois, 2007), enquanto que os investimentos exteriores diretos justificam a criação de grandes grupos empresariais ( na madeira, no cimento, no têxtil, etc.) que operam nas duas nações de forma indiferenciada. Talvez um indicador que expresse esta comunidade de interesses seja o número de trabalhadores que vivem de um lado da fronteira e se deslocam para o outro lado todos os dias, profissionais da saúde galegos ou trabalhadores da construção civil portugueses, estarâo entre os exemplos mais destacados, emvalres que, como veremos mais adiante, refletem perfeitamente a superação da fronteira na dimensâo prática e na vida quotidiana (EuroEures, 2007-2012).

Se a integração de vizinhança (à escala do local-nacional) resulta muito significativa no contexto de uma Europa mais unida, talvez mais relevante seja a opção que se abre à Galiza no contexto do mundo globalizado do presente. Sem dúvida, e seguindo os parâmetros clássicos da Geografia política (Taylor, 1994), a pertença da Galiza a Espanha justificou, pelo menos de forma massiva desde o século XVIII, um fluxo de migração para uma série de países americanos como Argentina, Uruguai, Cuba ou Venezuela, entre outros, vinculou a 
este território do Noroeste ibérico com a América hispana, onde o gallego foi sinónimo de espanhol recém chegado. Obviamente, os emigrantes adaptaram-se à forma de falar espanhola e à cultura desses países, que de uma forma ou de outra reintroduziam nas suas aldeias de origem de forma matizada. Este efeito, unido à escolarização massiva iniciada pelo Estado Espanhol no decorrer do século XIX e XX, supôs a implantação de um modelo mental hispano em milhares de galegos que estudavam a história nacional comum e o mapa de Espanha (com Portugal quase sempre em branco) (García Álvarez, 2001), e sentiam-se vinculados aos territórios irmãos do ultramar (García Sebastiani e Marcilhacy, 2013). Os fluxos migratórios dirigistas do período de 1050-1973 em direção à Europa mais desenvolvida reforçaram esta perceção, se bem que os vizinhos portugueses sempre seguiam um comportamento paralelo (em relação à América, também a do Norte, e obviamente França, Bélgica ou Alemanha, desde vilas e de aldeias muito semelhantes às que ficam a Norte do Minho). Os galegos emigraram para Portugal no século XVIII e mais tarde para o Brasil (González Lopo, 2006), mas esta experiência foi minimizada em relação ao enorme contingente humano que se deslocou para os países do Esteiro da Plata, ou a Cuba. Na Galiza, a hispanização natural e induzida foi progredindo, mas sem se perder o contacto com outro mundo próximo (pelo menos pela língua, cultura e interesses comuns) da lusofonia.

Os últimos anos redesenharam o mapa. A leitura hispana da Galiza mantém-se, agora com uma realidade reconhecida como Comunidade Autónoma (nacionalidade histórica), se bem que ao mesmo tempo as relações de todo o tipo com Portugal e países de língua oficial portuguesa não deixassem de progredir. Sem dúvida, isto resulta evidentemente nos âmbitos culturais e universitários, mas também em alguns círculos económicos, como é o exemplo destacado da pesca e da indústria associada, pelos notáveis interesses e negócios comuns que se foram densificando entre si e também com Cabo Verde, Guiné-Bissau, Angola e Moçambique. Alem disso, há a considerar a afirmação de um significativo lobby galego no Brasil, com negócios em hotelaria e de diversão noturna no Rio de Janeiro, comerciais, de construção civil ou da energia em Salvador da Bahia e em São Paulo, entre outros. Consequentemente, no mundo globalizado atual a leitura, o código geopolítico da Galiza começa a aproveitar uma dupla pertença, como já referimos ao hispano, mas também ao luso. Esta componente portuguesa que oferece muitas possibilidades com o vizinho europeu do Sul, mas que sobretudo permite numerosos contactos, oportunidades de negócio e cumplicidades com uma nova potencia emergente do Sul, o Brasil. A possibilidade de que um país com a capacidade de decisão no eixo mundial utilizar uma língua muito próxima e possuir uma cultura irmã mudou profundamente a leitura de milhares de galegos sobre a lusofonia, que também se estende por terras cheias de possibilidades como Angola ou Moçambique, entre outros. Portanto, o mundo globalizado 
que se desenvolveu recentemente recolocou a Galiza num espaço que nunca Ihe foi alheio, como o luso; talvez com uma novidade, a partir de um conjunto de possibilidades económicas, de cooperação académica e cultural, ou simplesmente de vizinhança, da qual já são conscientes os setores historicamente desvinculados do galeguismo ou do nacionalismo histórico, mas que apreciam as potencialidades que oferece uma região mundial que fala galego-português, e que cada vez tem mais capacidades de decisão em fóruns relevantes no mundo atual.

A partir desta longa apresentação que fizemos, o nosso discurso organiza-se em função de quatro grandes apartados, que enunciamos em seguida. Em primeiro lugar, reflexionaremos sobre o caráter da Galiza como confim Norte das áreas de cultura e língua lusófonas. Num segundo epígrafe, aborda-se a inserção da Galiza no contexto ibérico para, seguidamente, colocar o tema das suas relações económicas, comerciais e turísticas com países de língua oficial portuguesa; isto é, para centrarmos em terceiro lugar nas realidades tangíveis que oferece a lusofonia para esta Comunidade Autónoma situada no Noroeste do espaço estatal espanhol. Por fim, aludiremos à construção do imaginário luso, como um novo âmbito relacional da Galiza, procurando nas conclusões procurarão retomar algumas ideias já formuladas, a partir do argumento central do texto que insiste na definição de cenários de futuro para o território galego, baseado na sua tripla vocação europeia, atlântica e lusófona.

\section{No confim Norte das áreas de língua e cultura lusófona.} Apontamentos de Geografia Histórica.

O historiador e geopolítico catalão J. Vicens Vives afirmou há quase setenta e cinco anos que, enfrentando noções dominantes e dominadas pela existência de dois Estados-nação, que a Península Ibérica podia explicar-se segundo uma organização do espaço meridiana, em direção Norte-Sul (Vicens Vives, 1952). Desta forma, o alongamento da Coroa de Aragón ou dos Països Cataláns fazia-se evidente em relação ao Reino de Valencia e Mallorca, o Principado de Asturias teve a sua continuidade no Reino de León, logo no que a Castela e posteriormente na Nova Castela que sempre foi Andaluzia; da mesma forma, o Reino de Galicia foi a origem do Condado, que muito em breve seria Reino, de Portugal, organizando um espaço continuo na fachada atlântica da Península Ibérica. Sem dúvida, a Reconquista, entendida mais no sentido português de repovoação e nova ordenação do território deste o Norte em relação ao Sul (Ribeiro, 1945), contra uma mais discutível interpretação castelhana ou aragonesa de avanço militar demorado durante séculos, ajuda a entender a organização territorial da Ibéria. Uma organização que, no caso espanhol, priorizou uma leitura desde a Meseta central em relação às periferias (Bel, 2010; Boira, 2013), e que desde 
Portugal contrapôs as regiões setentrionais às meridionais, mais recentemente o litoral e interior (Ferrão, 2002), mas talvez deva ter em conta uma lógica de crescimento em grande eixos atlântico e mediterrâneo, urbanos e muito dinâmicos, que seguem uma continuidade iniciada há aproximadamente mil anos. De facto, as fronteira entre o galego e o minhoto eram muito difíceis de determinar no rural, os fluxos demográficos foram contínuos ao longo da história e só a adscrição de cidades e vila a uma determinada monarquia, a súa fortificaçao e, mais recentemente, o tratado de limites de 1864, o cartografado cuidadoso da fronteira e a militarização da mesma no tempo das ditaduras ibéricas do século XX ( o franquismo e o Estado Novo), conseguiram num breve período romper a continuidade natural através do vale do Minho ou das elevações montanhosas das Serras Meridionais e Trás-Os-Montes entre as áreas de Ourense, Chaves e Bragança (Lois, 2002).

Sem dúvida, um aspeto no que deverão aprofundar os estudos consiste em conhecer até que ponto as falas populares do Sul da Galiza e do Minho foram muito semelhantes, perfeitamente compreensíveis entre si, até a um momento tardio do século XX. É certo que atualmente, a imposição de uma norma de domínio lisboeta do português padrão (favorecida pola televisâo) ou de formulas parcialmente castelhanizadas no galego normativo, e a sua difusão nos dois territórios através do sistema escolar aprofundou as divisões. Porém, não se pode negar que ainda assim as proximidades léxicas e gramaticais entre as falas galegas e as portuguesas são notáveis, e que a partir de estímulos mínimos que tendam para a reintegração linguística, a mesma reafirmar-se-ia sem dificuldades em diversos âmbitos. Os empresários e negociantes galegos que visitam Portugal rapidamente se adaptam a expressar-se como os seus vizinhos lusos, os trabalhadores de construção civil portugueses conversam sem dificuldades com os seus companheiros galegos no trabalho e no tempo comum de lazer, professores e investigadores comunicam-se sem renunciar às suas falas originais e sem grandes dificuldades, e assim poderíamos continuar com múltiplos exemplos. Portanto, ainda que sem dúvida a fixação contemporânea de uma fronteira política internacional galego-portuguesa ten tido repercussões para a separação dos povos e sociedades raianas durante várias gerações, parece reversível historicamente, pelas possibilidades que oferece tanto a Europa unida como o processo de globalização. E, neste sentido, as falas usadas pelas pessoas constituem um magnífico indicador da separação/aproximação que se vai produzindo ao longo do tempo. Outro aspeto de entidade para compreender a distância gerada entre a Galiza e Portugal ( evidentemente, entre o galego e o português) remete-nos à história política de ambos os territórios, especialmente na Idade Moderna (Lois, 2002). Entre os séculos XVI e XIX a Galiza foi perdendo peso económico e institucional até praticamente desaparecer nas representações simbólicas da Coroa de Castela (Torres Villegas, 1852). Por um lado, a crise do Caminho de Santiago originada tanto pela Reforma protestante como pela situação de conflito permanente hispano-francês do mesmo período, assinalou o declive do poder galego e compostelano em termos económicos, políticos e de articulação territorial. Neste âmbito, o eixo predominante de comunicação do Oeste europeu durante a Idade Média, que conectava Santiago e Finisterra galega com o resto da Europa através da rota jacobeia, foi substituído por uma nova via hegemónica, a que ligava Sevilha (lugar de entrada das riquezas e dos produtos americanos) com os portos do Cantábrico dependentes do Reino de Castela (Gijón, Santander, etc.). Por tanto, Galiza abandonou a sua posição central e tornou-se 
periférica, as suas elites clássicas declinaram (como o arcebispado de Santiago) e algumas das modernas deslocaram-se para viver na Corte, agora imperial, de Castela. Resulta evidente que a Galiza beneficiou muito da modernização agrária que acompanhou a introdução de alguns cultivos americanos (nomeadamente o milho) (Villares, 1984), mas também é certo que o seu protagonismo político ou simplesmente regional diminuiu até níveis extremos (como no longo período do século XVII em que a sua representação nas Cortes de Castela correspondia a Zamora). O galego desapareceu praticamente de moda na escrita, e converteu-se numa língua unicamente popular. Pelo contrário, em toda esta etapa Portugal afirmou-se como um dos territórios mais dinâmicos da Europa, na vanguarda das descobertas ultramarinas e conseguiu manter a sua soberania nacional, primeiro com um pacto com Filipe II e posteriormente mediante uma Guerra da Restauração da qual saiu vitorioso. Consequentemente, a comparação de um novo Reino pujante, que começava a aproveitar a sua presença na América, Ásia e África, com um território do confim Noroeste da Península relegado e uma posição periférica no castelhano (no espanhol), não fez senão desaparecer a este último das imagens portuguesas; em todo o caso, reduzindo-se ao galego, aos galegos, a um qualificativo não muito longínquo da imagem depreciativa que os habitantes deste território recebiam por esta época em Madrid (consultem-se a este respeito as obras de autores tão emblemáticos como Cervantes, Quevedo, etc.).

Esta posição subordinada da Galiza também se expressou nos primeiros fluxos migratórios dos seus habitantes para Lisboa, Porto ou Douro no século XVIII, muito bem caraterizados pelo historiador D. González Lopo (González Lopo, 2006). Uma migração de substituição dos portugueses que partiam para o Brasil e outras colónias que, porém, não oculta que as sociedades portuguesa e galega foram desde há muito tempo fornecedoras de homens e mulheres para a América e posteriormente outros países mais desenvolvidos da Europa e de outros continentes. Como se tem reiterado, as regiões da fachada atlântica da Península Ibérica definiram um conjunto de sociedades emigrantes ao longo da história, da mesma forma que centenas de milhares de irlandeses, bretões, escoceses, galeses ou noruegueses também partiram para o exterior em períodos conhecidos do passado, na procura de uma melhores condições de vida. Sem dúvida, todos estes territórios acusaram tradicionalmente o seu caráter periférico, menos desenvolvido que alguns espaços centrais do continente, ao que adicionaram umas elevadas densidades rurais, que se traduziam claramente na disponibilidade de um volume insuficiente de terras em muitos casos, ou da ausência das mesmas para muitos em áreas de grandes propriedades. A tradiçâo migratória galega e portuguesa que une os dois povos, tanto na recriação (e mitificação) popular da mesma como pela existência de uns comportamentos muito semelhantes dos que partiram nas sociedades de acolhimento (Bacelar, 1994; Lois e Verdugo, 2006). Também os efeitos que teve o retorno na modernização das comunidades aldeãs de origem e o investimento em grandes volumes de capital gerados pelas remessas são muito semelhantes, e contribuíram para acentuar as mudanças no mundo rural e de vila de toda a Galiza e de boa parte de Portugal.

Uma consequência da migração ultramarina dos galegos foi a distinção que desde o inicio puderam fazer entre o mundo luso europeu (exemplificado por Portugal) e extraeuropeu (que possui como 
principal referente o Brasil, mas também as coletividades de portugueses presentes na Venezuela, América do Norte, costa africana, etc.). Assim, a leitura da lusofonia foi-se construindo cada vez mais complexa e matizada desde meados do século XX, e a imagem do Brasil começou a afirmar-se como bem diferenciada (também muito atrativa) da do país vizinho do Sul da Ibéria. Sem dúvida, o Brasil é bastante diferente de Portugal, cada vez se interpreta mais como uma autêntica potencia emergente, oferecendo inquestionáveis possibilidades de fazer negócio, onde grandes cidades como Salvador da Baia, Rio de Janeiro ou São Paulo não são completamente estranhas pela presença de coletivos galegos assentados nas mesmas desde há várias gerações. No que diz respeito aos PALOP, a descoberta tem sido mais serôdia. Somente quando os galegos começaram a procurar novos bancos de pesca, de crustáceos e polvo na costa africana, se teve conhecimento direto, primeiro de Angola e Moçambique, posteriormente da Guiné Bissau e Cabo Verde. Além disso, este conhecimento reforçou-se porque as populações destes lugares falavam algo muito semelhante ao galego e a comunicação facilitava as possibilidades de chegar a acordos. Por outro lado, as rotas internacionais de emigração dos cabo-verdianos chegaram a Galiza, sobretudo como mão de obra para a construção de uma grande fábrica de alumínio na costa norte do território, e em seguida para o trabalho na pesca, o que tem gerado a existência de uma coletividade bastante reconhecida e estudada desse país em povoações como Burela (Fernández González, 2006). Alem disso, a identidade galego-cabo-verdiana de centenas de filhos da primeira corrente migratória situou este país insular na perceção de proximidade da Galiza em épocas recentes.

\section{A Galiza atual no contexto ibérico.}

Nas páginas anteriores refletirmos sobre a personalidade especial que manifesta a Galiza dentro da Península Ibérica, pelo seu particular vínculo com Portugal, ao mesmo tempo que constitui um território periférico, mas integrado desde há séculos na estrutura do Estado Espanhol. Se nos debruçarmos sobre estas ideias, importa dizer que em épocas recentes o território galego afirmouse como uma Comunidade Autónoma histórica, isto é uma nacionalidade, das dezassete que conformam Espanha (Aja, 1999). Entre as mesmas, podemos assinalar também que se encontra no primeiro grau dos espaços que alcançaram a autonomia, juntamente com o País Basco e Catalunha. Nestes casos a manutenção de uma língua própria e, sobretudo, ter aprovado um Estatuto que fixava o autogoverno no passado (nomeadamente na II República, entre 1931 e 1936), foram determinantes para materializar esta consideração mais positiva (García Álvarez, 2002). Não obstante, e como é evidente, o nível de sentimento diferencial na sociedade galega é inferior ao expressado pelos bascos e pelos catalães. Sem dúvida, a minoração do território na Idade Moderna e a consciência (real ou não) de que nos encontramos perante um país mais pobre que o conjunto espanhol, ajudaram a explicar esta realidade (Lois, 2013). Na Galiza, em relação ao País Basco e à Catalunha, o sentimento independentista é muito débil, da mesma forma que as reivindicações de um nível de autonomia maior estão limitadas. E isto num contexto onde o galego, tal como o canário 
noutras latitudes, se sente como singular, bastante diferente no contexto estatal e ibérico. Talvez recorrendo a esta razão, alguns politólogos (Subiela, 2013), insistem em sublinhar o forte sentimento galeguista ou mesmo nacionalista da sociedade que habita a Galiza, ao mesmo tempo que os partidos de adscrição espanhola foram e são claramente hegemónicos em todas as consultas eleitorais que se têm vindo a fazer desde o começo do século XX. O território galego constitui uma autonomia nítida no contexto espanhol. singular pela sua proximidade com o atlântico e com o português, mais ibérica que a média, e pouco problemática para as decisões governamentais tomadas em Madrid que, em todo o caso, não conseguiram corrigir o atraso histórico desta Comunidade situada no confim noroeste e isolado por montanhas do restante Estado Espanhol.

Ao mesmo tempo que a Galiza funciona como uma realidade autonómica, configura um espaço próprio onde as conexões com Portugal se fazem mais evidentes. Como têm destacado diversos autores, na fachada atlântica da Península Ibérica produziu-se um intenso processo de urbanização e concentração demográfica as áreas litorais, que permite falar de uma cidade continua que se estende desde Ferrol - A Coruña até Lisboa e à península de Setúbal (Medeiros, 1987; Barata, 1992; Lois, 2004; Piñeira e Santos, 2011). Mesmo autores de renome internacional como o canadiano R. Florida insistem em que, a partir das imagens de iluminação noturna proporcionadas pelos satélites artificiais, o eixo urbano atlântico reflete uma maior intensidade de urbanização e ocupação humana que o corredor mediterrâneo alongado de Málaga a Barcelona e, evidentemente, que a região metropolitana de Madrid (López Carro, 2014). Segundo esta evidência, a área metropolitana do Porto situa-se numa posição central do eixo, com uma população que supera os dois milhões e meio de habitantes (incluindo o Cávado e o Ave), alongam-se em direção ao Norte para ligar em pouco mais de 100 quilómetros com a área de Vigo, que se estende pelo espaço urbanizado de PontevedraRías Baixas, e em 300 km, com Lisboa, através de áreas organizadas por Aveiro, Coimbra, Figueira da Foz, Leiria ou Santarém, para rematar numa região metropolitana que se expande para o Sul em direção a setúbal e contabiliza quase 3 milhões de residentes. Mais a Norte, Santiago de Compostela, e as suas periferias, e A Coruña-Ferrol expressam a continuidade urbana, da mesma forma que os concelhos situados na primeira parte da rota ente Porto e Vila Real, entre Vigo e Ourense ou entre Lisboa e Évora. Por tanto, encontramos uma das áreas que mais riqueza, emprego, capacidade de atrair investimentos e artificialização do solo demonstra em todo o Sul da Europa. Para a nossa argumentação, a existência deste eixo litoral não faz mais do que corroborar o processo de forte integração territorial que os espaços urbanos e de economia diversificada do presente mostram entre a Galiza e Portugal. Uma integração que se expressa na mobilidade continua da população de um lado para o outro da fronteira, em dinâmicas de deslocalização e colaboração empresarial e laboral, e que possui uma intensidade incomparavelmente maior que a estabelecida entre as cidades e vilas galegas e as suas homónimas de Castela e León ou Astúrias.

Tal como se tem insistido, as continuidades entre os espaços galego e português no contexto ibérico contrastam com relativo isolamento do eixo urbano atlântico em relação aos territórios do interior, em particular em relação à Região Metropolitana de Madrid. De facto, para a deslocação por autoestrada ou por ferrovia desde A Coruña, Santiago de Compostela, Vigo, Porto ou Lisboa para a 
capital do Estado Espanhol ou de outras cidades de Castela, Astúrias ou Andaluzia devem percorrerse quase sempre mais de $\mathbf{2 0 0}$ quilómetros de áreas pouco povoadas, rurais e caraterizadas pelo declive. Perante a litoralização galego-lusa, amplos espaços interiores expressam a distância subjetiva com outras áreas urbanas e metropolitanas da Península. Precisamente neste confim orientar do galego (e do português) encontramos comarcas de identidade dupla ou de transição, que alguns autores batizaram como a Galicia irredenta (López Mira, 1998). A mesma estender-se-ia desde o ocidente asturiano de falas galegas que chegam ao rio Navia, ainda que ninguém questione a sua pertença à Comunidade Autónoma do Norte, até a alta Sanabria correspondente à província de Zamora e raiana com Trás-Os-Montes, passando por todo o Bierzo, uma comarca de mais de 150.000 habitantes, de forte personalidade e com uns traços paisagísticos, culturais e de organização do território que se assemelham muito mais ao mundo galego que ao leonês e castelhano (Fernández Rei y Hermida, 1996; Babarro, 2003). Em todos estes setores se conservam falas galego-portuguesas, manifestações folclóricas e comunitárias muito semelhantes aos dos territórios situados no ocidente e bem individualizadas nas correspondentes à Meseta Espanhola. Estes traços, por vezes reconhecidos simbolicamente (escolarização optativa em galego, geminaçâo entre municípios, etc), são a constatação de que o galego vai mais além dos seus estritos limites administrativos. Mas, este facto indiscutível muito dificilmente se afirmará no futuro, já que implicaria reconhecer que a lusofonia entra mesmo em territórios pertencentes a Astúrias e Castela e León, algo inconcebível desde o imaginário tradicional espanhol. Na verdade, no ano de 2006 quando se realizaram alguns atos de defesa da candidatura do património imaterial galego-luso para a sua consideração como mundial pela UNESCO, surgiram vários protestos airados e crises de conteúdo político (sobretudo no ocidente asturiano), já que não se podia admitir a galeguización (em certa medida, lusofonização) de uma parte desta Comunidade Autónoma (Valcarcel, 2007). Em contrapartida, importa assinalar que mais ao Sul na fronteira hispano-lusa existem exemplos de afirmação lusófona ou do castelhano fora das suas fronteiras (Rio de Onor, Olivença, Barrancos, etc.) (Lois, Valcárcel e Escudero, 2000), uns exemplos que ou se ignoram desde as instâncias oficiais ou procuram reduzir-se a simples manifestações pontuais e folclóricas.

Um último apontamento sobre as relações de vizinhança galego portuguesas no marco geral definido por uma Ibéria dividida entre Espanha e Portugal, refere-se à leitura hegemonicamente espanhola que se faz da Galiza desde a sociedade portuguesa. Quando um visitante luso se dirige a Tui, Vigo ou Santiago de Compostela considera, e assim o verbaliza de forma frequente que "vai a Espanha". Só uma pequena minoria de habitantes da região do Minho ou da área do Porto percebem certa diferença (refletida num quadro de autonomia política) entre o galego e o restante espanhol. Desta forma, o galego não se concebe como uma língua própria à margem do espanhol ou da divisão hispano-lusa em dois Estados-nação ibéricos definidos pelos seus próprios idiomas, e a história da Galiza nunca é divergente da oficial de Espanha, ainda que uma abafante maioria de estudos sobre os períodos medieval e moderno demonstrem que o que se entende como español não deixa de ser castelhano ou resultado direto da ação de uns monarcas que só concebiam os seus territórios dependentes como um património próprio (Álvarez Junco, 2001). A imagem do galego em Portugal é muito débil, sempre menor do que a proporcionada pela cidade e o Caminho de Santiago, 
e contudo a nossa tese de uma melhor leitura da Galiza seria enormemente benéfica para a lusofonia. Isto por diferentes motivos: a) Como assinalamos em diversas ocasiões, a Galiza pode ser interpretada como um território de interseção entre o espanhol e o português. Pertencente a um Estado-Nação determinado, mantém os traços culturais, linguísticos e de vizinhança intensos com outro país ibérico, e isto deve ser tomado como uma vantagem no marco de um bom entendimento entre todas as partes, b) Com a consolidação do eixo urbano atlântico de Ferrol - A Coruña até Lisboa, as possibilidades de desenvolvimento deste amplo espaço aumentarão muito. Todo o planeamento estratégico que se materializa deve entender esta nova realidade, como já o fazem atualmente numerosos atores privados na altura de impulsionar os seus negócios; c) Neste espaço sem dúvida emergente, a relação e cooperação entre Porto e Vigo deve converter-se numa prioridade. Na realidade, com este amplo eixo urbano bem articulado, a posição central e metropolitano do Porto fica sublinhada, abrindo novas perspetivas à organização espacial da Península Ibérica; d) Claramente, uma intensificação dos vínculos Galiza-Portugal contribuiria a uma redefinição territorial de Espanha, hoje marcada pela hegemonia das regiões mediterrâneas; e) Neste contexto, uma excelente oportunidades para aprofundar o descobrimento e impulso da interpretação lusa da realidade galega deve ser a Estratégia 2020 da UE, onde se insiste em favorecer o crescimento inteligente, sustentável e integrador, precisamente três aspetos onde as sinergias Galiza-Portugal se evidenciarão muito.

\section{As relações económicas, comerciais e turísticas com os países de língua oficial portuguesa.}

Como complemento necessário às reflexões elaboradas sobre o papel da Galiza atual no mundo ibérico, é para nós fundamental a questâo da vizinhança geográfica e irmandade cultural de Galiza com Portugal e o resto do mundo lusófono. Isto é, como a cultura e a memória histórica levam à conformação de redes e espaços económicos bem definidos no quadro luso-galego num contexto de globalização. Esta procura só será inicial no presente artigo; deve ser completada por estudos que possam estabelecer modelos numéricos relativos à maior proximidade entre a Galiza, Portugal, Brasil e os PALOP pelo seu fator diferencial linguístico. Para este objetivo, abordaremos cinco aproximações complementares e breves no presente apartado. Em primeiro lugar, observaremos o que os dados nos oferecem sobre o comércio exterior e os Investimentos Exteriores Diretos (IED) entre a Galiza e a lusofonia numa perspetiva comparativa. Em segundo lugar, iremos repassar alguns registos gerais sobre a mobilidade quotidiana e os fluxos turístico-excursionistas com Portugal, o que se complementará com uma terceira questão sobre a acessibilidade tendo por referência a relaçâo Galiza-Portugal. Em quarto lugar, procuraremos isolar alguns traços gerais das relações com o Brasil, e terminaremos apontando que interesses setoriais e emergentes mostra a Galiza em relação aos PALOP. 
Para analisar os principais dados referidos aos intercâmbios económicos e de capital entre a Galiza e Portugal iremos recorrer a um extraordinário documento, o anuário A Economia Galega coeditado tradicionalmente pelo Instituto Universitario de Estudios para o Desenvolvemento de Galicia (IDEGA) da Universidade de Santiago de Compostela e a Fundacion Caixa Galicia, que na seção referida à indústria e elaborado por Joam Lopes Facal recolhe de uma forma precisa, e detalhada, o estado das relações entre a Galiza e o seu vizinho do Sul regularmente desde os anos 1980 ( IDEGA e Caixa Galicia, 1987-2013). Neste Anuário e em alguns trabalho que elaboramos há algum tempo, constatou-se a multiplicação do comércio exterior bilateral desde a integração dos países ibéricos na CE em 1986 e até ao início do século XXI, momento a partir do qual se deve falar de uma tendência para a estabilização (Lois, 2007). Durante os últimos dez ou doze anos é importante reter um dado sobre o comercio exterior da Galiza em direção a Portugal: o Estado luso situa-se, sempre e destacado, como segundo importador e exportador na balança comercial atrás de França, relarivamente à qual os interesses comuns na indústria automobilística justificam a sua preeminência (referimo-nos à presença da fábrica da empresa PSA em Vigo e os fluxos que gera). Este perfil difere do espanhol onde França e Alemanha aparecem como principais clientes e provedores, verificando-se que a importância de Portugal nos intercâmbios é reduzida.

A nível quantitativo, as exportações para Portugal representam o 17\%, o 13,1\% e o 13,0\% em 2010, 2011 e 2012 respetivamente, enquanto que as importações alcançaram os 12,7\%, 11,2\% e 11,9\% nesses mesmos três anos, o que corresponde a volumes de negócio entre 1600 e 1800 milhões de euros para as importações galegas e um valor mais variável de 2.000 a 3.000 milhões de euros nas exportações. Como já foi referido, esta sequência do comércio exterior sempre se traduz num superavit para a economia galega, continuo desde os anos de 1980 e que mostra o seu caráter mais competitivo em setores como o automóvel, o têxtil ou mais recentemente a energia (Meixide e De Castro, 1999; Lois, 2007; IDEGA e Caixa Galicia, 1987-2013). No que se refere à dinâmica expressada por estes dados, importa apontar duas ideias. A primeira, que a diminuição das compras realizadas na Galiza pelos portugueses no ano 2011 e 2012 está muito relacionada com a situação de crise económica aguda que está a sofrer o país (também constatável na Galiza) e que se traduz numa redução global dos números do comércio exterior. A segunda, que o pico do valor das exportações galegas em 2010 explica-se por um aumento das vendas de petróleo refinado da Corunha no mercado luso, importante transação que se mantém em 2011 e 2012, mas numas quantidades mais modestas (IDEGA e Caixa Galicia, 2011-2013).

Se passarmos a outro indicador relevante, os fluxos de capital expressados em Investimentos Exteriores Diretos (IED) para a Galiza, novamente se volta a demonstrar o protagonismo de Portugal, Brasil e o conjunto da lusofonia, assinalando outra vez um perfil distintivo relativamente ao conjunto espanhol. Por um lado, e este será o primeiro dado a reter, nos valores agregados de 1992 a 2012, Portugal destaca como a origem do $38 \%$ dos IED registados na Galiza, sem dúvida em grande parte como consequência da aquisição da empresa Cementos Cosmos e a sua integração na CINPOR, a companhia líder deste setor em Portugal (IDEGA e Caixa Galicia, 1987-2013). A CINPOR utilizou esta compra para se instalar em Espanha, através da empresa Corporación Noroeste, que possui a sua 
base operativa na cidade de Vigo na Galiza e contabiliza um total de 26 fábricas de cimento. $\mathrm{Na}$ realidade, a CINPOR apresenta-se como uma importante companhia transnacional deste setor com presença em até 12 países. Talvez seja por esta razão e pela profunda crise que sofre Portugal (pela questão da dívida pública), uma companhia que é emblemática da participação estatal na economia tenha sido privatizada progressivamente até à situação posterior a 2010 quando a maior das ações das suas açôes estâo na posse de empresas brasileiras e uma porção menor de entidades portuguesas. Concretamente, o Anuario da Economía Galega de 2011 lembra-nos que a CINPOR os grupos Camargo Correa e Votosantin de Brasil já possuem 32\% e o 21,1\% da companhia, frente a 10,7\% do português Manuel Fino, 10\% do Fundo de Pensões do BCP e 9,58\% da Caixa Geral de Depósitos (IDEGA e Caixa Galicia, 2011). Neste exemplo, estamos perante constituição de um importante grupo internacional baseado na lusofonia, mas não só no mais frequente eixo BrasilPortugal, senão também com recurso à Galiza como porta de entrada ao mercado espanhol. De facto, os maus resultados da Corporación Noroeste durante a crise ( que afetou de uma forma muito destacada o setor da construção), estimados em 12,3 milhões de euros em 2010, justificam a forte contribuição do capital brasileiro e português nesses anos na Galiza desde a matriz de CINPOR (IDEGA e Caixa Galicia, 2012). No Anuario de 2013 já se estima que os IED exteriores com destino à Galiza procedentes do Brasil e de Portugal representaram à volta dos $85 \%$ do total no exercício anterior (IDEGA e Caixa Galicia, 2013).

Outro âmbito onde a cooperação galego-lusa é relevante e gera contínuos fluxos de capital é a indústria mecânica, inicialmente centrada no setor automóvel, mas nos últimos anos se estendeu também á aeronáutica. De facto, a capacidade empresarial dos concelhos fronteiriços como o de Vila Nova de Cerveira, com três parques industriais, explica-se pelo processo de expansão do setor de acessórios de veículos desde a área de Vigo. Assim, no Anuario da Economía Galega de 2011 comenta-se como a importante companhia americana TRW, que fabrica airbags e volantes, já aparecia situada em Vigo (com duas fábricas), no Porriño e em Cerveira, expressando um processo natural de difusão do potencial industrial da grande cidade do sul da Galiza por espaços a sul da fronteira, no que se refere às empresas auxiliares do automóvel (IDEGA e CAIXA Galicia, 2011). Um movimento oposto, semelhante ao da CINPOR, mas também na indústria da mecânica é o constatado na COASA, progressivamente especializada na aeronáutica (fabricações de flaps e ailerons estabilizadores de aviões). A mesma colabora com a brasileira EMBRAER através da sua fábrica em Évora, que estabeleceu ligações com esta empresa de Ourense fortemente participada por capital português. Por tanto, estamos perante outro exemplo do eixo empresarial brasileiroluso-galego (IDEGA e CAIXA Galicia, 2012).

Um terceiro setor económico onde a conexão lusófona se observa sem dificuldade através de vários exemplos é o agroalimentar. Sem dúvida, dentro do mesmo a empresa que melhor simbolizou esta aposta foi a PESCANOVA de Vigo, especializada na comercialização de peixe congelado e refrigerado, assim como pratos preparados. Tradicionalmente PESCANOVA moveu-se com à-vontade no espaço galego-português, ampliado aos PALOP onde sempre manteve barcos a trabalhar. Uma das suas últimas grandes apostas investidoras consistiu em impulsionar uma importante unidade de 
aquicultura em Portugal, na Praia de Mira, que por ter problemas técnicos acabou por provocar enormes perdas. Estas perdas que antecedem a forte crise na que se afundou a empresa desde 2013, e que perspectiva na atualidade um futuro incerto para a mesma. Com uma especialização produtiva próxima, e níveis de solvência financeira muito mais elevados, situa-se as conserveiras galegas CALVO de Carballo e Jealsa de Boiro, bem introduzidas no mercado brasileiro. CALVO comprou no Brasil o grupo Gomes de Costa em finais de 2004 e na atualidade uma grande parte da sua faturação gera-se neste país, onde controla $40 \%$ do mercado da sardinha enlatada e $50 \%$ do atum (IDEGA e CAIXA Galicia, 2012). Por sua parte, Jealsa também está no Brasil através da conserveira Crosoe Foods desde 2010 e, como último apontamento relevante no setor agroalimentar, importa lembrar um movimento inverso: a importância do leite processado na Galiza por companhias de capital português, como é o caso de Celta-Lactogal (IDEGA e CAIXA Galicia, 2012).

Numa análise mais conjuntural, marcada pela gravidade da crise, podemos completar esta leitura da importante interpenetração das economias galega e portuguesa noutros setores empresariais, extensível a toda a lusofonia. Assim, segundo os dados de 2012 os IED portugueses na Galiza situaram-se como sextos por volume e os brasileiros em décimo. No primeiro caso, devido à compra da metalúrgica galega Megasa por uma empresa pública portuguesa, num quadro de investimento que se mantivera em 2013, a pesar das enormes dificuldades que enfrentou este país, no fornecimento de energia elétrica e comércio grossista (IDEGA e CAIXA Galicia, 2012-2013). Uma rápida revisão à dimensâo do investimento galego no exterior, neste último período caraterizado pela contração dos fluxos, permite-nos encontrar operações em pesca e em serviços financeiros em Portugal em 2011. Posteriormente, os fluxos de capital da Galiza para o Sul do Minho foram muito dirigidos à construção e ao setor das embarcações de recreio. Por último, os registos disponíveis para 2013 colocam os IED em Portugal como os quartos por volumes, débeis pela conjuntura económica, mas ainda asim num posto destacado no ranking total de países com os quais se faz negócio neste caso concentrado no aluguer imobiliário (IDEGA e CAIXA Galicia, 2012-2013).

Neste último período de dificuldades, e logo voltaremos a esta questão, o que sim se nota é um reforço das operações empresariais que implicam compras e vendas com o resto dos países da lusofonia, especialmente com o Brasil. Efetivamente, em 2012 esta potencia latino-americana colocou-se no quarto posto por volume de IED galegos recebidos, só atrás de França, Itália e África do Sul. O capital dirigido a este país concentrou-se no setor elétrico, na obtenção de energia eólica e hidroelétrica. No ano seguinte, o Brasil ascendeu ao segundo posto com investimentos preferenciais na indústria, nas áreas da metalúrgica e de fabricação de cimento e aço. (IDEGA e CAIXA Galicia, 2012-2013). Como se pode comprovar, os negócios Galiza-Brasil têm uma componente estratégica, pois são os setores da grande empresa e da produção fabril estrita onde se encontram a maioria dos fluxos de capital contabilizados. O Brasil é um território muito apetecido pelas indústrias galegas para operar, ao mesmo empo que a Galiza vê como uma porta não menor de chegada de dinheiro brasileiro empregando Portugal como primeira escala europeia. No ano de 2013 os dados do IED também nos surpreendem pela aparição de outros territórios de língua portuguesa nas listas de IED, 
com o que se ratifica a nossa ideia de cultura/língua e economia, correndo em paralelo em tempos da globalização. Assim, Timor Lesta foi o 40 destino de investimento exteriores galegos para esse ano, e Macau o 22ํㅡㄹ sendo que neste último caso, é mais uma vez a Corporação Noroeste está na origem de uma aproximação de capital para a construção de uma fábrica de cimento (IDEGA e CAIXA Galicia, 2012-2013).

Outro aspeto onde se pode medir a intensidade das relações galego-portuguesas é na mobilidade de população, tanto a quotidiana do domicilio ao lugar de trabalho que atravessa a fronteira, como a gerada pelas deslocações por motivo comercial ou turística. No que se refere ao primeiro caso, o observatório transfronteiriço Euro-Eures, financiado pela UE, elabora estatísticas bastante precisas (Euro-Eures, 2003-2012), o que permite ver que, no ano de 2012, 7.229 portugueses possuíam contratos de trabalho na Galiza enquanto existiam 1.668 galego na mesma situaçâo em Portugal, ou seja, que há quase 9.000 pessoas nacionais de um dos territórios que trabalham no outro, mesmo num período de aguda crise económica. A composição do contingente continua a ser maioritariamente de operários da construção civil portugueses no Norte do Minho e de trabalhadores qualificados, um bom número deles médicos e enfermeiros galegos no território vizinho do Sul (Euro-Eures, 2003-2012; Carballo, 2014). Este fluxo, como adiantamos, supôs uma certa contração do existente em épocas de crescimento económico já que em 2007 e 200816.626 e 20.644 portugueses tiveram contratos laborais na Galiza (da corrente inversa não se dispõe de registos da altura, ainda que parece que variou muito pouco). Dentro deste coletivo, a mesma fonte estima que para 2012 só 844 operários portugueses atravessavam a fronteira para desenvolver a sua jornada laboral na Galiza todos os dias ( eram 2.017 em 2007, o máximo histórico) frente a 615 galegos em direção oposta (Euro-Eures, 2003-2012). Isto implica que para uma grande parte dos portugueses que vão para a Galiza a deslocação possui um caráter semanal, o qeu acontece com aproximadamente $60 \%$ de galegos com emprego a Sul do Minho.

Outro dado relevante do fluxo galego-português quotidiano é o das Intensidades Médias Diárias (IMD) de circulação por estrada e autoestrada nas vias transfronteiriças. Neste sentido, importa lembrar que este tipo de mobilidade é amplamente hegemónica perante uma escassa utilização da ferrovia, condicionado por um serviço à população ainda muito deficiente. Nas vias rodoviárias, destaca-se a predominância do eixo do Minho, com 17.783 veículos que utilizaram a ponte nova TuiValença em 2009, um número muito destacado, representativo de um eixo de comunicações estruturante. Este valor reforça-se com os 5.463 que o fizeram entre Monção e Salvaterra, os 4863 também entre Melgaço e Arbo. Esta intensidade de tráficos que traduz a importância das relações entre ambos os lados no Minho/Miño, muito superior aos valores registados pela parte interior da fronteira: 755 carros entre Ponte Barxas e São Gregório, 767 na passagem de Lindoso, 787 entre Aceredo e Lindoso, 670 entre Baltar e Montalegre, 508 entre A Xironda e Santo André (Montalegre), nas passagems que superaram os 500 carros ou autocarros de trânsito diário, já que em 14 estradas Galiza-Portugal (no troço Ourense- Trás-Os-Montes) nem se alcançam estes valores. Apenas entre Chaves e Verín importa referir um fluxo também destacado, de 7.075 veículos por dia, o que reforça o papel central no transito deste setor menos habitado e desenvolvido da raia (Carballo, 2014). De 
todas as formas, o conjunto de IMD reflete uma mobilidade sobressaliente entre territórios cada vez mais próximos e acessíveis, onde os eixos de desenvolvimento de disposição meridiana se impuseram ao velho traçado da fronteira Oeste-Leste.

Nesta revisão da mobilidade transfronteiriça, apenas nos resta comentar outra fonte de estatísticas numéricas, a elaborada por TURGALICIA que desde os ano 1990 até 2010 publicou questionários de origem e destino turístico entre a Galiza e Portugal, que permitiram contabilizar com muita aproximação o volume de portugueses que vinham à Galiza aproveitar as suas férias ou simplesmente para compras ou lazer (mas neste caso não incluía dormida) (TURGALICIA, 19872010). Estes dados foram elaborados desde o Departamento de Estatística da Universidade de Santiago de Compostela e, desgraçadamente, a série foi interrompida em 2010 por problemas orçamentais. Dos valores obtidos no decénio anterior, e já utilizados em trabalhos prévios, deduz-se que os cidadãos de Portugal realizavam aproximadamente três milhões de deslocações para a Galiza por ano. Mais de noventa por cento desta mobilidade tinha por motivo declarado a realizaçâo de compras (sobretudo em direção a Vigo, mas também a Ourense, Tui ou Verín) e de lazer (restaurantes, locais noturnos, etc.) (Lois, 2007). Estes valores refletem umas relações muito intensas de vizinhança pelo menos entre os portugueses que moram a Norte do Douro e os galegos, relações que vão sempre alterando-se de acordo com a conjuntura económica de cada território: a oscilação que marca as séries históricas recolhidas vai de dois até seis milhões de viagens. A este respeito, deve-se referir que o fluxo de deslocações para a Galiza era vinte vezes superior desde Portugal que desde outras Comunidades Autónomas vizinhas de Astúrias e Castela-León, o que ratifica a ideia já expressa de uma lógica meridiana de articulação regional do enquadramento noroeste da Península Ibérica (Lois, 2007). Na desagregação dos dados à escala de NUT III verifica-se que a maior das pessoas que vinham à Galiza comprar ou aproveitar o seu tempo livre procediam do Minho-Lima, Alto Douro, de Trás-Os-Montes e do Grande Porto, por esta ordem. Contudo, tratandose de de turismo (viagens de mais de um dia) os valores situavam em primeiro lugar o Grande Porto, e a distância ao Ave e ao Tâmega (Lois, 2007). Relativamente aos perfis territoriais estudados, a percentagem das deslocações (sobre a população residente) eram muito mais elevadas no MinhoLima (perto de $30 \%$ das viagens de menos de um dia), do que em Trás-Os-Montes e Alto Douro (menos do 15\%) e o Cávado, Grande Porto e Ave (8-10\% do total). Por último, a série consultada ratifica-nos que o gasto em compras era o predominante (uns 40 euros em 2006), em relação aos dedicados à comida, viagem e lazer que não chegavam a 5 euros em cada caso (Lois, 2007).

Num registo de dados anual e mais recente (TURGALICIA, 2008), obtêm-se valores complementares. Assim, segundo o inquérito turístico sobre o total de visitantes estrangeiros, cerca de $18,2 \%$ eram portugueses, sendo a nacionalidade mais representada ( à frente do Reino Unido e da Alemanha). Em relação aos motivos da deslocação, o mais significativo era conhecer a cultura e os costumes (típico do turismo cultural e urbano), seguido da tranquilidade e o descanso e dos interesses simplesmente de férias (TURGALICIA, 2008). Isto é, expressado de forma diferente, um comportamento que the concedia muita importância ao destino de Santiago e do Caminho, ao disfrute de outras cidades, mas que claramente mantinha o seu interesse por destinos de sol e praia 
vizinhos (e transfronteiriços) de grande prestígio como Sanxenxo ou Baiona, entre outros. Por fim, note-se que os registos também afirmam dois perfis de estadias de férias, uma mais curta de 3 a 10 dias, junto a uma segunda clássica de 13/15 jornadas de média (TURGALICIA, 2008).

Tal como se pode deduzir nos parágrafos precedentes, Galiza e Portugal (especialmente o Norte do país) são dois territórios muito acessíveis, vizinhos e que aproveitam a proximidade. Esta acessibilidade traduz-se sobretudo em viagens de menos de duas horas, por autoestradas ou outras vias rápidas, a um lugar diferente mas com o qual se partilham múltiplas afinidades culturais e linguísticas. Adicionalmente, como se comprovou, a comunicação entre os dois territórios segue uma dominante meridiana (N-S ou S-N), e reflete a hegemonia urbana e demográfica das áreas litorais. Segundo o modelo que foi priorizado pela UE desde 1986, ano de incorporação da Península Ibérica nas instituições europeias, esta boa conexão realiza-se maioritariamente por vias terrestres de alta capacidade, autoestradas ou outras vias, já que a ferrovia continua a estar marginalizada nas políticas de transporte de Espanha e Portugal. Uma novidade que trouxe consigo esta notável melhoria da acessibilidade consiste na utilização comum de grandes terminais de transporte. $\mathrm{O}$ caso mais destacado, e não isento de polémica jornalística, é o suscitado pelo aeroporto Sá Carneiro do Porto, utilizado por dezenas de milhares de galegos para as suas deslocações por via aérea ou os portos de interesse geral e pesqueiro de Vigo, Marín, Viana do Castelo e Leixões utilizados por empresas do outro país para movimentar mercadorias. Por último, a acessibilidade também se reflete na utilização de serviços especializados das cidades galegas e portuguesas empregados por cidadãos do outro país, como determinados centros universitários (a Faculdade de Medicina de Santiago de Compostela, por alunos portugueses ou escolas superiores de arquitetura e enfermagem por galegos)e hospitais ( num fluxo importante em direção à cidade de Vigo).

Num plano diferente às intensas relações de vizinhança e integração entre Galiza e Portugal ( sobretudo desde a Regiâo Norte) importa referir brevemente os vínculos comerciais existentes com o gigante lusófono, Brasil. Para esta aproximação, complementária de alguns dados de negócios mútuos tratados nos parágrafos anteriores, empregaremos os registos publicados pelo Instituto de Comercio Exterior (ICEX) de España (ICEX, 2014). Nos mesmos, o primeiro que se ressalta apuntar para um forte progresso dos intercâmbios hispano-brasileiros no último decénio, quando se triplicaram as exportações desde o país europeu e aumentaram à volta de $70 \%$ as compras de produtos brasileiros. Sem dúvida, o caráter de potência emergente do Brasil expressa-se em volumes de negócio cada vez mais altos para um país com uma forte vocação económica orientada à América Latina. Entre as importações destaca-se sobretudo os frutos oleaginosos (provavelmente soja), os minerais e combustíveis, e entre as exportações espanholas também os combustíveis e lubrificantes, e os equipamentos, componentes e assessórios de automóveis (ICEX, 2014). Desta forma, parece que ainda se conserva um perfil de comércio típico das relaçôes Norte-Sul ou centroperiferia, entre recursos não elaborados por um lado e a maioria de bens industriais por outro. Nos últimos exercícios contabilizados na sua totalidade (de 2011 a 2013) o Brasil situa-se entre os postos 15 e 20 do ranking de países que comercializam produtos para Espanha, e numa posição similar em relação às vendas para este grande mercado ibérico (ICEX, 2014). Em função da mesma fonte, se nos 
centrarmos nos valores expressados pelo comércio exterior Galiza-Brasil, importa dizer que esta Comunidade Autónoma contabilizou entre $5 \%$ a $6,5 \%$ do total de exportações espanholas para o Brasil nos anos 2011 a 2013, um número equivalente à sua importância económica dentro do Estado, se bem que importa considera-la como mais elevada do que a generalidade das demais comunidaees, se considerarmos que a Catalunha arrecadou cerca de $30 \%$ dos registos totais do período analisado. No que se refere às importações desde o Brasil, e lembrando a sua componente principal de recursos alimentares e minero-energéticos, deteta-se um menor peso da Galiza que se estima entre um 1,7\% e um 3,1\% do total de compras espanholas de 2011 a 2013 . Aqui, novamente se destacam os registos de Catalunha, e na Galiza o forte domínio das províncias ocidentais dotadas de portos (A Coruña e Pontevedra, com Ferrol, A Coruña, Vilagarcía, Marín e Vigo como instalações marítimas) neste comércio exterior com a potência americana lusófona.

Por último, a consulta da mesma fonte do ICEX relativa a intercâmbios recentes, também nos mostra a aparição de relações emergentes muito localizadas entre Galiza e alguns dos PALOP, nomeadamente Moçambique e Angola (quadruplicaram-se as exportações e quase se multiplicamse as importações), se bem que a posição deste país no ranking comercial é irrelevante: entre o lugar 70 e 75 em importações e o 120/130 em exportações (ICEX, 2014). Para o que nos interessa aqui, surpreende que entre um 15\% e um 22\% das compras espanholas a Moçambique se realizem desde as províncias galegas no período de 2011-2014, em particular desde Pontevedra que praticamente totaliza o conjunto deste valor, o que se compreende pelas destacadas importações de alumínio abundante no território africano e que sustenta um setor de transformação especializado no litoral galego. No que se refere às exportações, Galiza apresenta valores muito flutuantes ano a ano, mas com certo significado (quase sempre a cima do $5 \%$ do total). Provavelmente se trate de um comércio pontual de produtos, novamente concentrado na sua quase totalidade na província de Pontevedra. Em relação a Angola, os seus intercâmbios com Espanha multiplicaram-se nos últimos anos (por seis as exportações e por doze as importações). As compras de hidrocarbonetos, e a muita distância de peixe e marisco, e as vendas de instrumentos para o sector da saúde e de automóveis, são os principais responsáveis desta pujança comercial, que situa Angola nos postos 65 a 70 do ranking de países para os quais exporta Espanha e entre o 20 e o 25 dos que importa. Se nos centrarmos na Galiza, novamente os valores de venda de bens ao território africano são extraordinariamente variáveis de um exercício para o outro, enquanto que as importações, focalizadas em Pontevedra, só tem um valor marginal no consumo do Estado. Assim, os PALOP começam a ser uns mercados interessantes, se bem que a Galiza não reflete um perfil de especialização, exceto no caso do alumínio moçambicano, e nos portos de Vigo, Marín e talvez Vilagarcía de Arousa. 


\section{A construção de um novo espaço relacional: o imaginário lusófono desde a Galiza.}

É evidente que a afirmação de que Portugal fica muito mais perto da Galiza que a Galiza de Portugal é certa, e os recentes dados de mobilidade transfronteiriça (na Euro-região Norte de PortugalGaliza), de professores e investigadores universitários no marco do Programa IACOBUS assim o confirmam (as estadias concedidas a estudantes, docentes e funcionários das universidades de Santiago de Compostela, A Coruña e Vigo duplicaram a dos portugueses procedentes dos politécnicos e universidades públicas do Norte abaixo do Minho). Como já se indicou, este desigual comportamento está muito relacionado com a leitura histórica e cultural de um território desde o outro. Destacados pensadores afirmaram em diversas ocasiões que o imaginário galeguista ou simplesmente nacionalista galego sublimou todo o que era português, ao mesmo tempo que se construía uma imagem negativa de Castela (Beramendi e Maiz, 1991). Portugal é vista como irmã separada pelos avatares históricos que se deveriam superar nos novos tempos, e Castela como expressão de uma Espanha dominadora, colonial, que submeteu a Galiza às suas formas de expressão desde finais do século XV (Castelao, 1944; Máiz, 1991; Beramendi, 2008). Contudo, esta leitura não se corresponde com a habitual em Portugal, Estado-nação afirmado após uma guerra de independência no século XVII, que se preocupou em defender de uma possível invasão espanhola, unificou todas as histórias regionais do país vizinho numa só (incluída a galega), e projetou todo o seu potencial económico e político além mar, no Atlântico, através de um importante império colonial e de uma aliança estratégica com os ingleses desde o XVIII. Pouco importava em Portugal a evolução de um pequeno território nos seus confins setentrionais, onde se falava um dialeto muito influenciado pelo espanhol (Lois, 2002). Só com a incorporação dos dois países à Europa unida é que esta leitura começa a mudar, mas para umas minoria, subretudo ligada à cultura portuguesa máis atenta às expressões literárias ou cientifica além Minho (talvez a consolidação da Universidade do Minho tenha ajudado bastante nisso). E minoritária na medida em que a generalidade dos cidadãos portugueses continua a pensar o mesmo em relação a uma Espanha concebida como unitária e monolítica, ainda que nos territórios minhotos e transmontanos esta interpretação apareça substancialmente alterada, e as noticias provenientes de Catalunha levem a uma nova reflexâo por alguns outros sobre a diversidade interior do que é visto como unidade política.

Partindo desta diferente perceção entre as sociedades galega e portuguesa, não se pode negar uma evidência na que insistimos ao longo de todo o presente texto: a utilidade do galego-português para os cidadãos de um e do outro lado da fronteira. Por um lado, os galegos que cruzam o Minho ou os postos fronteiriços do Alto Douro compreendem sem exceção, com maior ou menor grau de familiaridade, a forma de falar dos seus vizinhos do Sul. Mesmo em épocas recentes tem-se observado que os galegos que empregam habitualmente o espanhol na sua vida quotidiana passam a expressar-se com frases bem pensadas em galego quando vão a uma localidade portuguesa. Do outro lado, talvez ainda muitas pessoas que chegam a Vigo, Santiago ou a alguma povoação costeira continuem a entender que quase todos os seus interlocutores se expressam em espanhol ou em 
portunhol, quando o fazem em galego. Não obstante, e a pesar do que é visto como uma estranha insistência de bastantes portugueses em continuar a falar na língua oficial do grande país vizinho, é incontestável que os mesmos sentem claramente uma maior familiaridade linguística e comunicativa na Galiza do que em Andaluzia, Estremadura e Castela-León. Nas nossas observações constatamos que este problema não surge com interlocutores brasileiros, que descobrem na Galiza uma língua irmã, não submetida a uma leitura espanholizante ou dialetal que muitos portugueses fazem como expressão da sua leitura de um mapa ibérico constituído por dois Estados-Nação equivalente, na maioria dos seus personagens. Neste contexto, o que não se pode negar é que quando existe algum negócio, intercambio ou empresa que se desenvolve do outro lado da fronteira, a comunicação não se acompanha de nenhum problema, é fluída, e costuma fazer-se em galego-português. Também acontece o mesmo entre as pessoas, bastantes numerosas como vimos, que atravessam diária ou semanalmente o limite político Galiza/Portugal por motivo de trabalho, de compras e, em menor medida, de estudo e de lazer. Sem dúvida, construir da parte portuguesa uma imagem de proximidade, lusófona, do galego ajudaria muito a evitar certas disfunções comunicativas, que são no mínimo curiosas.

Como se apontou no parágrafo precedente, o comércio e os negócios unificam as falas do Norte e do Sul do Minho de forma natural. Por isso, uma questão relevante baseia-se em considerar que o português é uma língua útil para a economia. Esta facto surge como evidente para os muitos empreendedores galegos que fazem negócio ou trabalham em Portugal, Brasil ou na África Austral. Os mesmos, inequívocamente, comportam-se de uma forma semelhante aos estudantes portugueses que chegam a Santiago de Compostela para estudar medicina e descobrem uma cidade muito próxima simbólica e culturalmente, aos de enfermagem e arquitetura galegos que recorrem a Escolas Superiores situadas perto da fronteira e em Portugal, que em nenhum caso têm problemas de adaptação ou compreensão linguística no seu processo formativo. Não obstante, esta aceitação da língua portuguesa no Norte do Minho poderia ser maior se os estudos da ortografia e da fonética desta variedade linguística nacional do Sul se generalizassem como opção no ensino secundário dentro do sistema educativo institucionalizado galego. A este respeito, a aprovação da Iniciativa Legislativa Popular "Paz Andrade" pelo Parlamento Galego pode converter-se num começo nesta linha, se bem que a implementação prática dos seus conteúdos ainda é muito débil. Quando algum produto de massas dirigido aos mais novos reconheceu a existência de uma comunidade linguística galego-portuguesa comum, não apenas não causou problemas, como houve grande recetividade e seguimento, como aconteceu com o programa infantil Xabarín Club emitido vários anos pela Televisión de Galicia (TVG). Por outro lado, em Portugal também se avançará notavelmente quando se interprete o território galego como uma prolongação natural lógica e sem ruturas da área de negócio de numerosas empresas radicadas no Minho e nos espaços metropolitanos de Porto e de Lisboa.

Uma das nossas teses insiste em que o desaparecimento efetivo das fronteiras políticas favorece a mobilidade quotidiana de pessoas através da mesma. Esta mobilidade e aumento exponencial dos contatos normalizados entre galegos e portugueses reforça a utilidade da conformação de uma 
cultura, uma língua e expressão, e um espaço económico de lazer comuns. O Brasil facilita-se de forma natural (e reforça-se pela presença de comunidades históricas de emigrantes) e as possibilidades de ampliar os vínculos com os PALOP por parte da Galiza, constituem uma porta aberta para o futuro. $O$ mesmo se pode dizer da potencial projeção de Portugal em relação aos territórios célticos e atlânticos do Oeste europeu (Escócia, Irlanda, Bretanha, etc.) com que os galegos mantêm uma relação mais sólida, ou com os países da América Latina com uma forte pegada histórica das coletividades de gallegos, nome com a que os rioplatenses (no Uruguai e na Argentina) e os cubanos definem aos chegados de todo o Norte espanhol, assim como alguns brasileiros do Nordeste chaman galegos a todos os loiros.

Consequentemente, a opção por um galego integrado na lusofonia possui inumeráveis virtudes. Saise de um contexto de língua local ou rexional muito rica, bastante bem conservada, mas com ameaças evidentes devido à existência de um sentimento nacional galego muito mais débil que nos casos da Catalunha ou do País Basco, para um outro contexto amplificado de uma das famílias idiomáticas globais, faladas por centenas de milhões de pessoas, que têm muito a dizer no mundo crescentemente interrelacionado e intercomunicado atual. De uma forma similar, e como se apontou (Valcárcel, 2007), evita o risco evidente à dialetização do galego no espaço envolvente do espanhol, com um mudança geopolítica de indubitável interesse. Para a sociedade e as elites portuguesas (e brasileiras) aceitar a proximidade de todo o galego constitui uma oportunidade expansão cultural, económica e territorial muito importante para uma nação encravada uma longínqua esquina do sudeste europeu. Adicionalmente, na Galiza e em Portugal a presença visível ou subjacente do espanhol, permite formar coletividades de pessoas com habilidades bilingues em dois sistemas idiomáticos que, conjuntamente, som usadas por perto de 1.000 milhões de homens de mulheres em todo o Mundo.

\section{Como forma de conclusão. Os cenários de futuro para a Galiza: o reforço do seu perfil europeu, ibérico e lusófono.}

Ao longo do presente artigo defendeu-se que a integração entre Espanha e Portugal nas Comunidades Europeias em 1986 abriu uma nova fase nas relações entre a Galiza e o seu país vizinho do Sul. A fronteira política foi superada e agora importa insistir na melhoria das relações económicas, culturais e de vizinhança de todo o tipo. Para tanto, a questão europeia entendida no seu sentido tradicional de cidadania comum dos habitantes do mesmo continente revela-se num instrumento básico para reforçar as relações. Em maior medida, importa aproveitar os programas específicos da UE para o desenvolvimento territorial conjunto e a especialização inteligente (Interreg, POCTEP, RIS3, etc.). Sem dúvida, - velho sonho iberista de há mais de um século pode reinterpretar-se na lógica de 
integração de territórios e países limítrofes de Espanha e Portugal, que durante muito tempo (em particular no franquismo e no Estado Novo) estiveram forçados a viver de costas voltadas pelas autoridade governamentais dos dois Estados-nação.

Neste contexto, as complementaridades económicas, a vizinhança e a facilidade nas comunicações, uma organização tradicional do espaço muito semelhante e a simpatia existente entre as duas comunidades ajuda muito a uma crescente integração. Desta forma, e como insistimos na tese central deste artigo, a reivindicação da pertença a uma família linguística e cultural comum galego-portuguesa é o fator mais importante para a construção deste território transnacional. De facto, que os galegos comecem a compreender que são uma parte específica da lusofonia é fundamental, num processo paralelo à assunção por parte da sociedade portuguesa de que existe um território bastante individualizado em Espanha, onde se conserva uma forma de falar próxima á sua, e que supõe uma prolongação natural do espaço económico nacional por toda a fachada atlântica da Península Ibérica. Os passos para a incorporação da Galiza no mundo lusófono beneficiam todas as pates; agora importa defendê-lo com intensidade, ao mesmo tempo que se articulam campanhas positivas de sensibilização cidadã, capazes de demonstrar que Galiza mais Portugal é muito mais do que a soma dos dois.

\section{Referências bibliográficas}

AJA, E. (1999): El Estado Autonómico. Federalismo y hechos diferenciales. Madrid: Alianza Ed. ÁLVAREZ JUNCO, J. (2001): Mater Dolorosa. La idea de España en el siglo XIX. Madrid: Taurus ANDERSON, B. (1983): Imagined Communities: Reflections on the Origin and Spread of Nationalism. Londres: Verso.

BABARRO GONZÁLEZ, X. (2003): Galego de Asturias. Delimitación, caracterización e situación sociolingüística (2 volumes). A Coruña: Fundación Barrié

BACELAR, J. (1994): Galegos no paraíso racial. Salvador de Bahia: Centro Editorial e Didáctico-UFBA.

BARATA SALGUEIRO, T. (1992): A Cidade em Portugal. Uma Geografia urbana. Lisboa: Ed. Afrontamento.

BEL, G. (2010): España, capital París. Origen y apoteosis del Estado radial: del Madrid sede cortesana a la "capital total". Barcelona: Ed. Destino.

BERAMENDI, X. (2008): De Provincia a Nación. Historia do galeguismo político. Vigo: Xerais.

BERAMENDI, X. G e MÁlZ, R. (Comp. ) (1991): Los nacionalismos en la España de la llạ República. Madrid: Siglo XX Ed.

BOIRA, J.V. (2013): "Infraestructuras y financiación en España: hacia un nuevo paradigma", en J. GÓMEZMENDOZA, R.C. LOIS y O. NEL.LO (Eds.), Repensar el Estado. Crisis económica, conflictos territoriales e identidades políticas en España. Pp. 101-114. Santiago de Compostela: Grupo ANTE y Servicio de Publicacións da USC. 
CARBALLO LOMBA, A. (2014): A mobilidade transfronteiriza na Eurorrexión Galiza-Norte de Portugal. Traballo Fin de Máster. Master Oficial en Planificación y Gestión del Desarrollo Territorial. Universidade de Santiago.

CASTELAO, A.D. (1944): Sempre en Galiza. Buenos Aires: Artes Gráficas Bartolomé U.

EIXO ATLÁNTICO (2004): Galicia, Norte de Portugal: dúas rexións. Unha rexión construíndo a Europa dos cidadáns. Santiago de Compostela: Eixo Atlántico do Noroeste Peninsular e Comunidade de Traballo da Eurorrexión Galicia-Norte de Portugal.

EURO-EURES (2007-2012): Informes periódicos de movilidad laboral transfronteriza. Vigo y Valença do Minho: Euroeures. https://ec.europa.eu/eures/public/

FERNÁNDEZ GONZÁLEZ, L. (2006): "Evoluçao da comunidade cabo-verdiana residente na Marinha luguesa", en LOIS GONZÁLEZ, R.C. e VERDUGO MATES, R.M. (Eds.), As Migracións en Galiza e Portugal. Contributos desde as Ciencias Sociais. Pp. 217-237. Santiago de Compostela: Candeia Ed.

FERNÁNDEZ REI, F. e HERMIDA GULÍAS, C. (1996): A nosa fala. Bloques e áreas lingüísticas do galego. Santiago de Compostela: Consello da Cultura Galega

FERRAO, J. (2002): "Portugal, très geografias em recombinaçào; espacialidades, mapas cognitivos e identidades territoriais", en Lusotopie. Portugal, une identité dans la longue durée. Num. 10, 2002/2. Pp. 151-159. Paris: Ed. Karthala.

GARCÍA ÁLVAREZ, J. (2001): "La nación visualizada: cartografía, propaganda y enseñanza escolar en la España del franquismo", AGE y Universidad de Oviedo, Departamento de Geografía, Actas del XVII Congreso de Geógrafos Españoles. Pp. 58-61. Oviedo: AGE y Universidad de Oviedo.

GARCíA ÁlVAREZ, J. (2002): Provincias, Regiones y Comunidades Autónomas. La formación del mapa político español. Madrid: Temas del Senado.

GARCÍA SEBASTIANI M. e MARCILHACY, D. (2013): "América y la fiesta del 12 de octubre", en J. Moreno Luzón y X.M. Núñez Seixas (eds.), Ser españoles. Imaginarios nacionalistas en el siglo XX. Pp. 364-399. Barcelona: RBA Ed.

GONZÁLEZ LOPO, D. (2006): "Se se mudasem embora nao haveriaquem servisse...Os galegos en Portugal: un exemplo típico de mobilidade en época preindustrial", en R.C. Lois e R.Mà. Verdugo (Ed.), As migracións en Galiza e Portugal: contributos desde as Ciencias Sociais. Pp. 237-265. Santiafo de Compostela: Candeia Ed.

HOWSBANN, E. (1983): The Invention of Tradition. Cambridge: Cambridge University Press.

ICEX (2014): Estadísticas del comercio exterior español. Madrid: Gobierno de España.

IDEGA-Caixa Galicia (1987-3013): Informe da Economía Galega (anuarios). Fundación Caixa Galicia: A Coruña.

LOIS GONZÁLEZ, R.C. (2002): "As relaçóns de Portugal com a Ibéria: uma olhada desde a Galiza". Lusotopie, no. 10, 2002/02. Pp. 193-211. Paris: Karthala.

LOIS GONZÁLEZ, R.C. (2004): “Estructura territorial de Galicia”, en R. Rodríguez González (Dir.), Os concellos galegos para o século XXI. Análise dunha reestructuración do territorio e o goberno local. Vols. I e II. Pp. 100161. Santiago de Compostela: IDEGA-Universidade de Santiago.

LOIS GONZÁLEZ, R.C. (2007): Fronteras y análisis geográfico; la raya galego-portuguesa. Trabajo Original e Inédito presentado a la Habilitación para el Cuerpo de Catedráticos de Universidad, del área de conocimiento de Análisis Geográfico Regional. Granada.

LOIS GONZÁLEZ, R.C. (2013): "Recursos económico-financieros y equidad territorial en España" en J. GómezMendoza, R.C. Lois y O. Nel.Lo (Eds.), Repensar el Estado. Crisis económica, conflictos territoriales e identidades políticas en España. Pp. 63-77. Santiago de Compostela: Grupo ANTE y Servicio de Publicacións da USC.

LOIS GONZÁLEZ, R.C.; VALCÁRCEL RIVEIRO, C. e ESCUDERO GÓMEZ, L.A. (2000): "El hecho diferencial en el Estado Español: un estudio geográfico desde la periferia", en Lois, R., Martín Lou, Mạ.A., Mata, R y Valenzuela, M., Vivir la diversidad en España. Aportación española al XXIX Congreso de la Unión Geográfica Internacional, Seul 2000. Pp. 219-243. Madrid: Comité Español de la Unión Geográfica Internacional. 
LOIS GONZÁLEZ, R.C. e VERDUGO MATES, R.M. (Eds.) (2006): As Migracións en Galiza e Portugal. Contributos desde as Ciencias Sociais. Santiago de Compostela: Candeia Ed.

LÓPEZ CARRO, M.R. (2014): Lectura xeográfica da cidade de Porto. Traballo Fin do Grao de Xeografía e Ordenación do Territorio. Presentado en la Facultade de Xeografía e Historia. Universidade de Santiago.

LÓPEZ MIRA, A.X. (1998): A Galicia Irredenta. Vigo: Ed. Xerais.

MÁlZ, R.(1991): "Federalismo y nación en el discurso del nacionalismo gallego de la IIa República", en Beramendi, X. G e Máiz, R. (Comp. ) (1991): Los nacionalismos en la España de la IIạ República. Pp. 377-405. Madrid: Siglo XX Ed.

MEDEIROS, C.A. (1987): Introduçâo à Geogragia de Portugal. Lisboa: Ed. Estampa.

MEIXIDE, A.. e DE CASTRO, A. (Coords.): Galicia e a Rexión Norte de Portugal: un espacio económico europeo. A Coruña: Fundación Caixa Galicia.

MORENO LUZÓN, J. r NÚÑEZ SEIXAS, X.M. (2013): Ser Españoles. Imaginarios nacionalistas en el siglo XX. Barcelona: RBA Eds.

PAPELES DE ECONOMÍA ESPAÑOLA (1994): Galicia y Norte de Portugal. Claves económicas de una eurorregión. Núm. 22. Madrid: Fundación de las Cajas de Ahorros.

PIÑEIRA MANTIÑÁN. Mạ.J. e SANTOS SOLLA, X.M. (2011): Xeografía de Galicia. Vigo: Ed. Xerais.

RIBEIRO, O. (1945): Portugal, o Mediterráneo e o Atlántico. Lisboa: Sá da Costa.

SUBIELA, X. (2013): Para qué nos serve Galicia? Vigo: Ed. Galaxia.

TAYLOR, P. (1994): Geografía Política: Economía-Mundo, Estado Nación y Localidad. Madrid: Trama Ed.

TORRES VILLEGAS, J. de (1852): El Mapa político de España. Imp. de José Mạ. Alonso.

TURGALICIA (1987-2010): Enquisa en orixe e Enquisa en destino. Análise estatística sobre o turismo en Galicia, series anuais. Santiago de Compostela: Xunta de Galicia e Universidade de Santiago.

VALCÁRCEL RIVEIRO, C. (2007): Xeolingüística da periferia románica atlántica: línguas e lugares. Tese de Doutoramento. Departamento de Filoloxía Galega. Universidade de Santiago de Compostela.

VICENS VIVES, J. (1952): Aproximación a la Historia de España. Madrid: Centro de Estudios Históricos Internacionales.

VILLARES, R. (1984): A Historia. Vigo: Ed. Galaxia, Biblioteca Básica da Cultura Galega. 